\title{
PENGARUH USAHA KOORDINASI, INTEGRASI STRATEGIS, ORIENTASI PASAR, DAN INOVASI PRODUK TERHADAP KINERJA PEMASARAN PADA TOKO BOMBAY TEXTILE INDONESIA
}

\author{
Patrick Wangsa \\ Program Studi Magister Manajemen Universitas Tarumanagara \\ patrick.wangsa@hotmail.com \\ Rina Adi Kristianti \\ Program Studi Magister Manajemen Universitas Tarumanagara
}

\begin{abstract}
Every monthly sales value in Stores Bombay Textile Indonesia in the year continued to increase in 2016, although in the sector that data showed sales decline. The purpose of this research is to know the effect of coordination effort, strategic integration, market orientation, and product innovation simultaneously on marketing performance At Bombay Textile Indonesia Store. The research method used in this research using explanotory reseach type or research form through associative research, survey method is data collection conducted on the object in the field by taking samples from a population by using questionnaires. The number of samples in the study amounted to 105 respondents. Data analysis technique used multiple linear regression analysis. The results showed that partially coordination efforts have a positive effect on marketing performance. Strategic integration positively affects marketing performance. Product innovation has a positive effect on marketing performance Market orientation has a positive effect on marketing performance. Simultaneously coordination efforts, strategic integration, market orientation, and product innovation simultaneously affect the marketing performance At Bombay Textile Indonesia
\end{abstract}

Keywords: business coordination, strategic integration, market orientation, product innovation, marketing performance

\section{PENDAHULUAN}

Toko Bombay Tekstil masih tetap bertahan bahkan penjualanya meningkat dari tahun ketahun. Hal ini dapat dilihat pada tabel 1 dibawah ini.

Tabel 1 Penjualan rata-rata perbulan Toko Bombay Textile Indonesia (dalam Jutaan)

\begin{tabular}{ccc}
\hline No & Tahun & Penjualan (dalam jutaan rupiah) \\
\hline 1 & 2012 & 853,25 \\
2 & 2013 & 825,14 \\
3 & 2014 & 873,58 \\
4 & 2015 & 912,25 \\
5 & 2016 & 924,56 \\
\hline
\end{tabular}

Sumber: Toko Bombay Textile Indonesia, 2017

Berdasarkan data diatas didapatkan nilai penjualan rata-rata perbulan pada tahun 2012 sebesar Rp. 853,25 juta dan terus mengalami peningkatan pada tahun 2016 sebesar 924,56. peningkatan penjualan tersebut tidak bisa terlepas dari kinerja pemasaran dan faktorfaktor yang mempengaruhi kinerja pemasaran.

Penelitian yang dilakukan oleh Mohamad (2012) mengungkapkan bahwa usaha koordinasi dan integrasi strategis berpengaruh positif dan signifikan terhadap kinerja pemasaran perusahaan. Hal berbeda diungkapkan oleh Anis (2002) yang menyatakan bahwa usaha koordinasi tidak berpengaruh terhadap kinerja pemasaran, akan tetapi integrasi strategis berpengaruh positif dan signifikan terhadap kinerja pemasaran. Penelitian lain 
tentang orientasi pasar dan inovasi produk yang diteliti oleh Lapian (2016) dan puspitasari (2015) yang mengungkapkan bahwa orientasi pasar dan inovasi produk secara parsial berpengaruh positif dan signifikan terhadap kinerja pemasaran. Perbedaan hasil penelitian terdahulu yang tidak konsisten menarik untuk di teliti tentang pengaruh usaha koordinasi, integrasi strategis, orientasi pasar dan inovasi produk terhadap kinerja Pemasaran pada Toko Bombay Textile Indonesia.

\section{TUJUAN PENELITIAN}

Tujuan dalam penelitian ini adalah:

1. Untuk mengetahui pengaruh usaha koordinasi terhadap kinerja Pemasaran pada Toko Bombay Textile Indonesia

2. Untuk mengetahui pengaruh integrasi strategis terhadap kinerja Pemasaran pada Toko Bombay Textile Indonesia

3. Untuk mengetahui pengaruh orientasi pasar terhadap kinerja Pemasaran pada Toko Bombay Textile Indonesia

4. Untuk mengetahui pengaruh inovasi produk terhadap kinerja Pemasaran pada Toko Bombay Textile Indonesia

\section{TINJAUAN PUSTAKA}

\section{Kinerja Pemasaran}

Kinerja pemasaran merupakan ukuran prestasi yang diperoleh dari aktifitas proses pemasaran secara menyeluruh dari sebuah perusahaan atau organisasi, kinerja pemasaran juga dapat dipandang sebagai sebuah konsep yang digunakan untuk mengukur sampai sejauh mana prestasi pasar yang telah dicapai oleh suatu produk yang dihasilkan perusahaan (Adiputra, 2014). Nasution (2014) mengemukakan indikator yang digunakan dalam mengukur kinerja pemasaran berupa Efektivitas perusahaan, Pertumbuhan penjualan, dan Pertumbuhan keuntungan relative

\section{Usaha Koordinasi}

Usaha koordinasi adalah sebagai suatu usaha yang mampu menyelaraskan pelaksanaan tugas maupun kegiatan dalam suatu organisasi. Koordinasi merupakan suatu usaha yang sinkron dan teratur untuk menyediakan jumlah dan waktu yang tepat, dan mengarahkan pelaksanaan untuk menghasilkan suatu tindakan yang seragam dan harmonis pada sasaran yang telah ditentukan yaitu meningkatkan pemasaran (Hasibuan, 2011). Usaha koordinasi dilakukan dalam menggerakan tim dengan memberikan lokasi kegiatan pekerjaan yang cocok dengan masing-masing dan menjaga agar kegiatain itu dilaksanakan dengan keselarasan yang semestinya diantara para anggota itu sendiiri. Pengaruh usaha koordinasi terhadap kinerja pemasaran dapat dilihat dari seberapa besar koordinasi perusahaan dalam kerjasamnya memperlancar penjualan, dimana dengan lancarnya penjualan maka akan dapat meningkatkan kinerja pemasaran, disamping itu usaha yang dilakukan perusahaan dalam hal memanfaatkan peluang yang ada dan pemecahan masalah akan dapat meningkatkan kinerja pemasaran perusahaan. Perusahaan dengan koordinasi kurang baik akan berdampak pada kinerja pemasaran. Mohamad (2012) mengemukakan usaha koordinasi dapat diukur menggunakan indikator Kerjasama dalam Memperlancar penjualan, Usaha memberikan peluang, Usaha mendapatkan transaksi, Kendala/ kesulitan, dan Upaya Pemecahan Masalah

\section{Integrasi Strategik}

Integrasi stratejik merupakan upaya perusahaan untuk mengintegrasikan sumber daya yang dimilikinya dengan sumber daya perusahaan lain dengan maksud memperoleh hasil yang lebih besar, dimana jika tidak berintegrasi secara strategis maka hasil itu tidak dapat dicapai. Upaya perusahaan untuk mengintegrasikan sumber daya yang dimilikinya dengan 
sumber daya perusahaan lain dengan maksud memperoleh hasil yang lebih besar, dimana jika tidak berintegrasi secara makasimal maka kinerja pemasaran tidak akan maksimal. Integrasi yang dilakukan oleh perusahaan akan mempermudah distribusi produk yang dihasilkan perusahaan untuk didistribusikan ke tangan konsumen, dengan hal tersebut akan meningkatkan kinerja pemasaran. Segala keuntungan dari integrasi strategik dalam kerjasama antar perusahaan harus secara langsung maupun tidak langsung akan meningkatkan kinerja perusahaan bagi para mitranya (Handoko, 2005). Hal tersebut merupakan proses inovasi, keuntungan-keuntungan manajemen logistik, waktu tanggap yang lebih singkat serta transaksi-transaksi yang efisien yang semuanya menunjang efektifitas dan efisiensi kerja dalam melayani pemasaran mereka.

\section{Orientasi pasar}

Orientasi pasar sebagai penetapan sasaran konsumen strategis dan membangun organisasi yang berfokus pada layanan konsumen, memberikan dasar persaingan yang berfokus ke dalam, memberi layanan yang sesuai dengan harapan para konsumen, sehingga berhasil memenangkan suatu persaingan. Orientasi pasar merupakan sesuatu yang penting bagi perusahaan sejalan dengan meningkatnya persaingan global dan perubahan dalam kebutuhan pelanggan dimana perusahaan menyadari bahwa mereka harus selalu dekat dengan pasarnya. Orientasi pasar merupakan budaya bisnis dimana organisasi mempunyai komitmen untuk terus berkreasi dalam menciptakan nilai unggul bagi pelanggan (Tjiptono, 2011). Orientasi pasar sebagai penetapan sasaran konsumen strategis dan membangun organisasi yang berfokus pada layanan konsumen, memberikan dasar persaingan yang berfokus ke dalam, memberi layanan yang sesuai dengan harapan para konsumen, sehingga berhasil memenangkan suatu persaingan. Boleh dikatakan orientasi pasar adalah cara yang dilakukan organisasi untuk mengidentifikasi pasar dan menggunakannya sebagai dasar untuk menentukan strategi perusahaan. Perusahaan-perusahaan yang berhasil dalam mengendalikan pasar yaitu perusahaan yang selalu menempatkan orientasi pelanggan dan orientasi pesaing secara harmonis, sehingga menghasilkan kinerja pemasaran yang lebih baik sehingga dengan kemampuan tersebut perusahaan akan mendapatkan kinerja pemasaran yang maksimal. Pertiwi (2014) mengemukakan bahwa orientasi pasar dapat dijabarkan dalam indikator Kondisi pasar, Tuntutan konsumen, Keinginan pelanggan, dan Strategi yang dilakukan competitor

\section{Inovasi Produk}

Inovasi produk adalah bagian dari karakter kerja yang menghubungkan budaya perusahaan dengan kemampuan berinovasi serta meningkatkan kinerja, pemasaran dan inovasi dipandang sebagai pendorong pertumbuhan ekonomi dan komponen utama dari keunggulan bersaing. Inovasi produk merupakan salah satu faktor persaingan yang paling penting untuk kesuksesan dimana akhir-akhir ini lingkungan bisnis selalu berubah dengan cepat. Oleh karena itu adanya inovasi diharapkan dapat mengeliminasi kendala yang di alami oleh perusahaan dalam mengenalkan produk kepada konsumen. Inovasi merupakan bagian dari karakter kerja yang menghubungkan budaya perusahaan dengan kemampuan berinovasi serta meningkatkan kinerja, pemasaran dan inovasi dipandang sebagai pendorong pertumbuhan ekonomi dan komponen utama dari keunggulan bersaing. Inovasi dalam hal produk maupun proses sangat bergantung pada penciptaan teknologi. Inovasi adalah bagaimana sebuah atau seseorang menghasilkan uang dari kreativitas. (Djodjobo, 2014). Dengan melakukan inovasi dalam bidang bisnis, maka perusahaan bukan hanya dapat menghadapi pesaing, tetapi juga tantangan ketika kreativitas berada pada kultur organsasi yang benar, yang hasilnya adalah inovasi. inovasi secara klasik yaitu, merupakan konsep luas yang antara lain dalam implementasi dari ide-ide baru, produk ataupun proses. Dengan memaksimalkan inovasi maka kinerja pemasaran dapat ditingkatkan. 


\section{Hipotesis}

H1 : Ada pengaruh positif dan signifikan antara usaha koordinasi terhadap kinerja pemasaran

$\mathrm{H} 2$ : Ada pengaruh positif dan signifikan antara integrasi strategik terhadap kinerja pemasaran

H3 : Ada pengaruh positif dan signifikan antara orientasi pasar terhadap kinerja pemasaran

H4 : Ada pengaruh positif dan signifikan antara inovasi produk terhadap kinerja pemasaran

\section{METODE PENELITIAN}

Jenis atau bentuk penelitian explonatory reseach melalui penelitian asosiatif, yaitu penelitian yang digunakan untuk mengetahui hubungan dua variabel atau lebih (Sugiyono, 2015). Tempat dalam penelitian ini adalah Toko Bambay Textile Indonesia. Populasi penelitian adalah karyawan dari berbagai bagian pada Toko Bombay Textile Indonesia sebanyak 105 karyawan. Teknik pengambilan sampel yang digunakan adalah total sampling, yang berarti teknik pengambilan sampel dengan mengambil seluruh populasi sebagai sampel penelitian (Ghozali, 2011). Pengambilan sampel dengan cara mengalikan 5 parameter dengan jumlah indikator pertanyaan sehingga jumlah sampel minimal yang diambil dalam penelitian ini adalah 5 dikalikan 21 yaitu 105 sampel. Jumlah sampel dalam penelitian ini adalah 105 responden. Dalam penelitian ini terdapat empat variabel bebas yaitu usaha koordinasi (X1), integrasi strategis (X2), orientasi pasar (X3) dan inovasi produk (X4) serta satu variabel terikat yaitu kinerja pemasaran (Y).

Teknik analisis data menggunakan anlisis regresi linier berganda, pengujian hipotesis penelitian menggunakan uji $t$ dan untuk mengetahui persentase pengaruh variabel independen terhadap variabel dependen menggunakan uji koefisien determinasi (R Square Adjusted).

\section{HASIL PENELITIAN DAN PEMBAHASAN}

Dalam penelitian ini, uji regresi dilakukan untuk mengetahui pengaruh dan besar pengaruh dari variabel independen terhadap variabel dependen. Analisis regresi linier berganda perlu memenuhi uji Asumsi klasik. Pengujian asumsi klasik dilakuan menggunakan uji normalitas berikut ringkasan uji normalitas

Tabel 2 Ringkasan Hasil uji normalitas menggunakan rumus Kolmogorov smirnov

\begin{tabular}{|c|l|c|c|c|}
\hline No & \multicolumn{1}{|c|}{ Variabel } & $\begin{array}{c}\text { Uji kolmogorov } \\
\text { smirnov }\end{array}$ & $\geq \mathbf{0 . 0 5}$ & Kesimpulan \\
\hline 1 & Kinerja Pemasaran & 0.058 & $\geq 0,05$ & Normal \\
\hline 2 & Usaha Koordinasi & 0.098 & $\geq 0,05$ & Normal \\
\hline 3 & Integrasi Strategik & 0.058 & $\geq 0,05$ & Normal \\
\hline 4 & Inovasi produk & 0.054 & $\geq 0,05$ & Normal \\
\hline 5 & Orientasi Pasar & 0.155 & $\geq 0,05$ & Normal \\
\hline
\end{tabular}

Sumber : Data Primer yang Diolah, 2018

Hasil uji normalitas data penelitian didapatkan hasil bahwa nilai signifikasi dari uji kolmogorov smirnov didapatkan hasil untuk masing-masing variabel lebih besar dari 0,05 sehingga data penelitian berdistribusi normal. Uji asumsi klasik dari uji multikolinieritas didapatkan hasil sebagai berikut

Tabel 3 Ringkasan Hasil uji multikolinieritas

\begin{tabular}{|c|l|c|c|}
\hline No & \multicolumn{1}{|c|}{ Variabel } & Tolerance & VIF \\
\hline 1 & Usaha Koordinasi & 0.476 & 2.101 \\
\hline 2 & Integrasi Strategik & 0.455 & 2.197 \\
\hline 3 & Inovasi produk & 0.855 & 1.170 \\
\hline 4 & Orientasi Pasar & 0.610 & 1.639 \\
\hline
\end{tabular}

Sumber : Data Primer yang Diolah, 2018 
Hasil uji multikolinieritas dapat dilihat bahwa nilai VIF untuk masing masing variabel yaitu variabel usaha koordinasi sebesar 2,101, variabel integrasi strategik sebesar 2,197, variabel inovasi produk sebesar 1,170 dan variabel orientasi pasar sebesar 1,639. Nilai VIF lebih kecil dari 10 sehingga persamaan regresi untuk masing-masing variabel tidak terdapat multikolinieritas.

Berdasarkan hasil perhitungan SPSS sebagai berikut:

Tabel 4 Ringkasan Hasil Persamaan Regresi

\begin{tabular}{|c|l|c|c|c|c|}
\hline $\begin{array}{c}\text { Variabel } \\
\text { dependen }\end{array}$ & \multicolumn{1}{|c|}{$\begin{array}{c}\text { Variabel } \\
\text { independen }\end{array}$} & $\begin{array}{c}\text { Std. } \\
\text { Coefisien }\end{array}$ & $\begin{array}{c}\text { T } \\
\text { hitung }\end{array}$ & Sig. & Keterangan \\
\hline \multirow{2}{*}{$\begin{array}{c}\text { Kinerja } \\
\text { pemasaran }\end{array}$} & Usaha Koordinasi & 0.143 & 3.159 & 0.002 & Ha diterima \\
\cline { 2 - 6 } & Integrasi Strategik & 0.135 & 2.930 & 0.004 & Ha diterima \\
\cline { 2 - 6 } & Inovasi produk & 0.169 & 3.132 & 0.002 & Ha diterima \\
\cline { 2 - 6 } & Orientasi Pasar & 0.135 & 2.271 & 0.025 & Ha diterima \\
\hline
\end{tabular}

Sumber : Data Primer yang Diolah, 2018

Hasil uji t dapat dideskripsikan bahwa hipotesis yang menyatakan usaha koordinasi berpengaruh positif dan signifikan terhadap kinerja pemasaran terbukti atau diterima karena nilai t hitung $(3,159)>t$ tabel $(1,660)$ dan nilai signifikasi sebesar $0,002<0,05$. hipotesis yang menyatakan integrasi strategik berpengaruh positif dan signifikan terhadap kinerja pemasaran terbukti atau diterima dengan nilai $t$ hitung $(2.930)>t$ tabel $(1,660)$ dan nilai signifikasi sebesar $0,004<0,05$. Hipotesis yang menyatakan inovasi produk berpengaruh positif dan signifikan terhadap kinerja pemasaran terbukti atau diterima dengan $\mathrm{t}$ hitung $(3,132)>\mathrm{t}$ tabel $(1,660)$ dan nilai signifikasi sebesar $0,002<0,05$. Hipotesis yang menyatakan orientasi pasar berpengaruh positif dan signifikan terhadap kinerja pemasaran terbukti atau diterima dengan nilai $t$ hitung sebesar $(2,271)>t$ tabel $(1,660)$ dan nilai signifikasi sebesar $0,025<0,05$.

Tabel 5 Uji Koefisien Determinasi dan uji F

\begin{tabular}{|l|c|c|c|c|c|}
\hline \multicolumn{1}{|c|}{ Variabel } & R & R Square & $\begin{array}{c}\text { Adjusted R } \\
\text { Square }\end{array}$ & F & Sig. \\
\hline $\begin{array}{l}\text { Pengaruh usaha koordinasi, integrasi } \\
\text { strategik, inovasi produk dan orientasi pasar } \\
\text { terhadap kinerja pemasaran }\end{array}$ & 0,762 & 0,581 & 0,564 & 34.648 & $.000^{\mathrm{a}}$ \\
\hline
\end{tabular}

Sumber : Data Primer yang Diolah, 2018

Hasil uji ANOVA, F hitung sebesar 34,468 dengan tingkat signifikansi pada $0,000<0,05$. Artinya usaha koordinasi, integrasi strategik, inovasi produk dan orientasi pasar secara simultan berhubungan dengan terhadap kinerja pemasaran. Tabel uji determinasi menunjukkan nilai adjusted $\mathrm{R}$ Square sebesar 0,564, dimana variasi dari variabel kinerja pemasaran dapat dijelaskan oleh variabel usaha koordinasi, integrasi strategik, inovasi produk dan orientasi pasar sebesar 56,4\%, sedangkan sisanya sebesar $43,6 \%$ dijelaskan oleh faktor-faktor lain diluar persamaan ini.

\section{PEMBAHASAN}

\section{Pengaruh Usaha Koordinasi Terhadap kinerja Pemasaran}

Koordinasi merupakan suatu usaha yang sinkron dan teratur untuk menyediakan jumlah dan waktu yang tepat, dan mengarahkan pelaksanaan untuk menghasilkan suatu tindakan yang seragam dan harmonis pada sasaran yang telah ditentukan yaitu meningkatkan pemasaran. Usaha koordinasi dilakukan dalam menggerakan tim dengan memberikan lokasi kegiatan pekerjaan yang cocok dengan masing-masing dan menjaga agar kegiatain itu dilaksanakan dengan keselarasan yang semestinya diantara para anggota itu sendiiri. Pengaruh usaha koordinasi terhadap kinerja pemasaran dapat dilihat dari 
seberapa besar koordinasi perusahaan dalam kerjasamnya memperlancar penjualan, dimana dengan lancarnya penjualan maka akan dapat meningkatkan kinerja pemasaran, disamping itu usaha yang dilakukan perusahaan dalam hal memanfaatkan peluang yang ada dan pemecahan masalah akan dapat meningkatkan kinerja pemasaran perusahaan. Perusahaan dengan koordinasi kurang baik akan berdampak pada kinerja pemasaran. Hasil penelitian menunjukan bahwa usaha koordinasi berpengaruh positif terhadap kinerja pemasaran, hasil penelitian sejalan dengan penelitian Anis (2002) dan Mohammad (2012) dalam penelitianyan mengungkapkan bahwa usaha koordinasi memberikan pengaruh terhadap kinerja pemasaran

\section{Pengaruh Integrasi Strategik Terhadap Kinerja Pemasaran}

Upaya perusahaan untuk mengintegrasikan sumber daya yang dimilikinya dengan sumber daya perusahaan lain dengan maksud memperoleh hasil yang lebih besar, dimana jika tidak berintegrasi secara makasimal maka kinerja pemasaran tidak akan maksimal. Integrasi yang dilakukan oleh perusahaan akan mempermudah distribusi produk yang dihasilkan perusahaan untuk didistribusikan ke tangan konsumen, dengan hal tersebut akan meningkatkan kinerja pemasaran. Segala keuntungan dari integrasi strategik dalam kerjasama antar perusahaan harus secara langsung maupun tidak langsung akan meningkatkan kinerja perusahaan bagi para mitranya. Hal tersebut merupakan proses inovasi, keuntungan-keuntungan manajemen logistik, waktu tanggap yang lebih singkat serta transaksi-transaksi yang efisien yang semuanya menunjang efektifitas dan efisiensi kerja dalam melayani pemasaran mereka. Hasil penelitian menunjukan bahwa integrasi strategik berpengaruh positif terhadap kinerja pemasaran. Hasil serupa diuangkapkan oleh Mohammad (2012) dan Anis (2002) mengungkapkan bahwa integrasi strategik yang dilakukan oleh perusahaan berdampak pada kinerja pemasaran

\section{Pengaruh Inovasi Produk Terhadap Kinerja Pemasaran}

Inovasi produk merupakan salah satu faktor persaingan yang paling penting untuk kesuksesan dimana akhir-akhir ini lingkungan bisnis selalu berubah dengan cepat. Oleh karena itu adanya inovasi diharapkan dapat mengeliminasi kendala yang di alami oleh perusahaan dalam mengenalkan produk kepada konsumen. Inovasi merupakan bagian dari karakter kerja yang menghubungkan budaya perusahaan dengan kemampuan berinovasi serta meningkatkan kinerja, pemasaran dan inovasi dipandang sebagai pendorong pertumbuhan ekonomi dan komponen utama dari keunggulan bersaing. Inovasi dalam hal produk maupun proses sangat bergantung pada penciptaan teknologi. Inovasi adalah bagaimana sebuah atau seseorang menghasilkan uang dari kreativitas. Dengan melakukan inovasi dalam bidang bisnis, maka perusahaan bukan hanya dapat menghadapi pesaing, tetapi juga tantangan ketika kreativitas berada pada kultur organsasi yang benar, yang hasilnya adalah inovasi. inovasi secara klasik yaitu, merupakan konsep luas yang antara lain dalam implementasi dari ide-ide baru, produk ataupun proses. Dengan memaksimalkan inovasi maka kinerja pemasaran dapat ditingkatkan. Hasil penelitian menunjukan bahwa inovasi produk berpengaruh positif terhadap kinerja pasar. Hasil serupa juga diungkapkan oleh Djodjobo (2014) dan Muangkot (2015) yang menyatakan bahwa inovasi produk merupakan bagian dari perusahaan dalam rangka meningkatkan kinerja pemasaran dan inovasi produk berpengaruh terhadap kinerja pemasaran.

\section{Pengaruh Orientasi Pasar Terhadap Kinerja Pemasaran}

Orientasi pasar merupakan sesuatu yang penting bagi perusahaan sejalan dengan meningkatnya persaingan global dan perubahan dalam kebutuhan pelanggan dimana perusahaan menyadari bahwa mereka harus selalu dekat dengan pasarnya. Orientasi pasar merupakan budaya bisnis dimana organisasi mempunyai komitmen untuk terus berkreasi dalam menciptakan nilai unggul bagi pelanggan. Orientasi pasar sebagai penetapan sasaran konsumen strategis dan membangun organisasi yang berfokus pada layanan konsumen, memberikan dasar persaingan yang berfokus ke dalam, memberi layanan yang 
sesuai dengan harapan para konsumen, sehingga berhasil memenangkan suatu persaingan. Boleh dikatakan orientasi pasar adalah cara yang dilakukan organisasi untuk mengidentifikasi pasar dan menggunakannya sebagai dasar untuk menentukan strategi perusahaan. Perusahaan-perusahaan yang berhasil dalam mengendalikan pasar yaitu perusahaan yang selalu menempatkan orientasi pelanggan dan orientasi pesaing secara harmonis, sehingga menghasilkan kinerja pemasaran yang lebih baik sehingga dengan kemampuan tersebut perusahaan akan mendapatkan kinerja pemasaran yang maksimal. Hasil penelitian menunjukan bahwa orientasi pasar berpengaruh positif terhadap kinerja pemasaran. Hasil penelitian penelitian sejalan dengan penelitian yang dilakukan oleh Bakti (2011) dan Suparman (2017) yang menyatakan bahwa orientasi pasar berpengaruh terhadap kinerja pemasaran.

\section{KESIMPULAN DAN SARAN}

Berdasarkan uraian hasil penelitian maka dapat disimpulkan bahwa Usaha koordinasi berpengaruh positif terhadap kinerja pemasaran sehingga semakin baik usaha koordinasi maka kinerja pemasaran juga akan semakin baik. Integrasi strategik berpengaruh positif terhadap kinerja pemasaran sehingga semakin baik integrasi strategik maka kinerja pemasaran juga akan semakin baik. Inovasi produk berpengaruh positif terhadap kinerja pemasaran sehingga semakin baik inovasi produk maka kinerja pemasaran juga akan semakin baik. Orientasi pasar berpengaruh positif terhadap kinerja pemasaran sehingga semakin baik orientasi pasar maka kinerja pemasaran juga akan semakin baik.

Saran yang dapat diberikan sebagai alternatif dari penelitian ini di masa mendatang adalah Hasil penelitian usaha koordinasi disarankan bagi organisasi perlu untuk menganjurkan pada karyawan berinovasi dalam pekerjaan serta memberikan kebebasan dalam melakukan langkah kerja baik itu didalam perusahaan maupun diluar perusahaan sehingga akan berdampak pada kinerja pemasaran. Seperti melakukan usaha dalam memberikan peluang dan mengupayakan pemecahan masalah dengan diskusi. Hasil penelitian tentang integrasi strategik, disarankan pada kerjasama yang menguntungkan terhadap mitra dan mempertahankan hubungan baik dengan pelanggan. Hasil tentang inovasi produk dapat disarankan pada perusahaan perlu mengembangkan dan menampilkan produk dalam bentuk berbeda dengan pesaing. Hasil tentang orientasi pasar dapat disarankan pada perusahaan perlu bersikap terbuka untuk menerima kritik dari konsumen sesuai dengan tuntutan konsumen dan secara periodik mengkaji ulang usaha- usaha pengembangan produk untuk menjamin bahwa produkproduk sesuai dengan keinginan konsumen.

\section{DAFTAR PUSTAKA}

Adiputra, Ricky. 2014. Pengaruh Orientasi Pasar Terhadap Kinerja Perusahaan (Studi Pada Hotel Kelas Melati di Yogyakarta). Jurnal Fakultas Ekonomi Universitas Atma Jaya Yogyakarta. P. 1-12

Anis, Mohamad. 2002. Koordinasi dan Integrasi Strategik Bagi Peningkatan Kinerja Pemasaran. Jurnal Sains Pemasaran Indonesia, Vol. I No. 2 Sept 2002 p. 198-218

Bakti, Sukma. 2011. Pengaruh Orientasi Pasar Dan Nilai Pelanggan Terhadap Kinerja Pemasaran Maskapai Penerbangan Lion Air. Jurnal Manajemen Pemasaran Modern, Vol. 3 No. 1, 2011. ISSN: 2085-0972. P. 1-15

Djodjobo, Cynthia Vanessa. 2014. Pengaruh Orientasi Kewirausahaan, Inovasi Produk, Dan Keunggulan Bersaing Terhadap Kinerja Pemasaran Usaha Nasi Kuning Di Kota Manado. Jurnal EMBA Vol. 2 No. 3 September 2014. ISSN: 2303-1174. P. 12141224.

Ghozali, Imam. 2011. Aplikasi Analisis Multivariate Dengan Program IBM. SPSS 19 (edisi kelima). Semarang: Universitas Diponegoro 
Handoko, T. Hani, 2005. Manajemen Personalia dan Sumber Daya Manusia, Yogyakarta: B.P.F.E. UGM.

Hasibuan, Malayu S.P. 2011. Manajemen Sumber Daya Manusia. Jakarta: PT Bumi Aksara

Lapian, Adelina Agnes. 2016. Pengaruh Orientasi Pasar dan Inovasi Produk Terhadap Kinerja Pemasaran Pada PT BPR Prisma Dana Amurang. Jurnal EMBA Vol. 4 No. 1 Maret 2016. ISSN: 2303-1174. P. 1330-1339

Mohammad, Sulaiman. 2012. Pengaruh Usaha Koordinasi dan Integrasi Strategik Terhadap Peningkatan Kinerja Pemasaran. Jurnal Fakultas Ekonomi dan Bisnis Universitas Negeri Gorontalo

Muangkhot, Sureerat. 2015. Strategic Marketing Innovation And Marketing Performance: An Empirical Investigation Of Furniture Exporting Businesses In Thailand. Journal International Trade And Academic Reseach Conference (ITARC) Vol. 7 no. 1 Nov 2015. P. 189-205

Nasution, Aulia Arief. 2014. Analisis Kinerja Pemasaran PT Alfa Scorpii Medan. Jurnal Riset Akuntansi dan Bisnis. Vol. 14 No. 1 Maret 2014 Univeristas Muhammadiyah Sumatera Utara

Pertiwi, Yunita Dwi. 2014. Pengaruh Orientasi Pasar Terhadap Kinerja Pemasaran Pada Umkm Kripik Buah Di Kota Batu. Jurnal Syariah Paper Acounting FEB UMS. ISSN: 2460-0784. P. 231-238

Puspitasari, Ratih Hesty Utami. 2015. Orientasi Pasar Dan Inovasi Produk Sebagai Strategi Untuk Meningkatkan Kinerja Pemasaran Perusahaan Mebel Jepara. Jurnal Kebangkitan teknologi Universitas Muria Kudus. P.135-148

Sugiyono. 2010. Metode Penelitian Kombinasi (Mixed Methode). Bandung: Afabeta

Suparman. 2017. Market Orientation, Product Innovation on Marketing Performance Rattan Industry in Cirebon Indonesia. IOSR Journal of Economics And Finance (IOSRJEF). Vol. 8 Issue 1 Ver III ISSN: 231-5925. P. 19-25.

Tjiptono, Fandy. 2011. Strategi Pemasaran. Edisi 3. Yogyakarta : ANDI. 


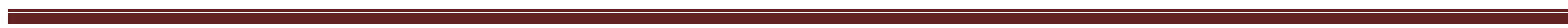
$\cdot$ 